\title{
Reformation Versus Nationality Problems in the Great Poland Province Before the Partitions of Poland
}

The relationship between nationality and religion is a major problem in all areas where various languages are spoken. Religious awareness was a very important sphere of social awareness, and it is thought today that to the populace it was the only form of reflective bond. The role played by the Reformation in that regard in Central and Eastern Europe, in areas of the German settlement penetration, was both significant and complex. ${ }^{1}$ Its substantial contribution to the development of national cultures and literary activity in many languages is well known. On the other hand, the exogenous German population was everywhere more susceptible to the Reformation than indigenes and consequently in some specific conditions Lutheranism undoubtedly played a Germanizing role. In Poland there is a clear connection between the Reformation and the rise of the Renaissance culture in its early stages, but what emerged in time was a polarity between nationality and religion, and a stereotype which occupies a very important place in our mentality today: Pole = Catholic, German = Protestant. On the other hand, it was a specificity of the Great Poland region that with the release of relatively accurate statistical data in the nineteenth century, which registered not only religion but also language, that stereotype turned out to be very close

1 This article relies on the results of a work by Z. Kaczmarczyk, Kolonizacja niemiecka na wschód od Odry, Poznań, 1945; and on the chapters devoted to the Reformation in a collective work titled Dzieje Wielkopolski, vol. 1, Poznań, 1969. 
to reality, much closer than in other districts of the Prussian Partition, that is, in East Pomerania or Silesia. But that situation developed in the preceding three centuries and it will be the subject matter of this article.

As we know the crux of a stereotype is that it does not reflect reality, but is only its simplified image, a form of irrational thinking. The reality, and in this particular case, the distribution of Polish and German, as well as Catholic and Protestant population, across Great Poland is the subject matter of a completely different area, the demographic and settlement studies. The methodological problems they involve are well known. Information about religion is not only incomplete, but also comes from subsequent periods. The oldest records of the visitation of the Poznan diocese come from 1603, of the Gniezno one - from 1608, and of the Kamień Krajeński archdeaconate - from 1652-53, and it was as late as the second half of the seventeenth century that figures were sometimes offered on the number of Catholics and a-Catholics in individual parishes. One may infer their nationality based on incidental sources and by means of highly fallible criteria, and the information thus compiled does not always overlap in time and space with that about religion. If for the eighteenth century it is possible to produce slightly more accurate estimates about the Polish and German populations, it is so only based on an assumption that a nationality actually overlaps with religion.

We should, however, begin with the moment when the Reformation arrived in the Polish lands. The question of the range and size of the German colonization of Great Poland has - as we know - raised numerous controversies. In consequence, one has a relatively clear picture of the relations in that regard at the turn of the Middle Ages and modern times, though the Historical and Geographical Dictionary (Stownik historyczno-geograficzny), which is being prepared, will undoubtedly provide more accurate information. There were three major concentrations of German settlement in the peripheries which later became part of the united Polish state. In the Wałcz land, in western corners of the Poznan powiat, and in the Wschowa land. There is no doubt today that in the Wałcz land Germans lived in villages and towns of the Drahim starostwo (Draheim Starostei) and in the north-western part of the Wałcz starostwo, in the estates of the Golc, Wedel and Blankenburg noble families. In the western areas of the Poznan powiat the German nationality was 
represented by some nobility and peasants living in both private lands and in the lands of large Cistercian abbeys in Paradyz and Bledzew. There was a large German majority living in the town of Międzyrzecz, and even more numerous one in Skwierzyna, and a small town of Brojce in the Babimost starostwo was also German. Smaller groups of Germans might have also lived on the eastern side of a line of lakes connected by the Obra River which is a natural border of the region. Their third concentration lived in the Wschowa land where many noble families from Silesia had settled. They lived along a borderline which was hard to define in linguistic terms. There were several German villages which were both in private hands and owned by the Przemęt Abbey. Wschowa was more German than Międzyrzecz. ${ }^{2}$

Of those three regions the least integrated with the rest of Great Poland was the land of Wałcz, although it can hardly be said to have been of homogeneously German character, and it became a powiat with its own court as late as 1554. However, it inherited from the Brandenburg rule an expanded liege system which did not exist in the lands that were inhabited by indigenous Polish population. Equally significant was the fact that it enjoyed a significant ecclesiastical independence; the deaconate of Wałcz also covered the areas belonging to Neumark, it was under the jurisdiction of a judicial vicar resident in Kalisz Pomorski, and the local clergy tolerated the authority of the Poznan bishop with a conspicuous aversion. ${ }^{3}$ But it seems unlikely that the economy of those regions inhabited by the German population had any specific features that would make it different from the rest of that province. It is also worth remembering that the state border was not a line separating two nationalities, but that it cut across areas that were mixed in language terms. Deep inside Great Poland the remnants of Medieval German settlement were quickly becoming extinct. While in Kościan Germans were still a significant national minority, in Poznan their community was very small.

We can say next to nothing about the relations between the Polish and German populations. There is hardly a period in the history of Poland when one would not come across traces of Polish-German antagonism,

2 Of vital significance is still the work by K. Tymieniecki, 'Niemcy w Polsce', Roczniki Historyczne, 12, 1936, 2, pp. 198-276.

3 J. Nowacki, Dzieje archidiecezji poznańskiej, vol. 2, Poznań, 1964, pp. 240-41. 
although it had different meanings to different social strata and groups and comprised various stages. ${ }^{4}$

Polish nobility continued to feel resentment due to the former claims of the German Empire to the supremacy over Poland. But more important to the wide masses was a fresh memory of wars with Teutonic Knights. Bigger towns were ridden by an antagonism between the advancing Polish element and the German elite trying to maintain power, which undoubtedly was the case of Poznań. The attacks by nobility on the German culture in towns were in fact ill-concealed attacks on municipal self-government. We do not know if everyday contacts between neighbours in small towns and villages were ridden with any antagonisms, or if they lived peacefully side by side. The Polonization process did undoubtedly cover the German nobility settled in Poland and burghers of those towns where they constituted a minority. A very important question must therefore remain unanswered: if Germans felt that their linguistic and cultural distinctness was threatened.

Great Poland bordered on the states where the Reformation had just been adopted: Western Pomerania, Neumark, Brandenburg and Silesian duchies. Before the official Lutheran Church was established, the Reformation spread in those territories quite spontaneously among nobility and burghers, and also among peasants, though on a smaller scale. The Reformation ideas were propagated by runaway monks, students returning from Wittenberg and uneducated demotic preachers; merchants smuggled books in bales of fabrics, itinerant craftsmen circulated songs. The Reformation reached Polish lands in a similar way, though little is known about it, and its penetration was inevitable given frequent family and professional contacts between members of the German community on both sides of the border. However, everything seems to indicate that for the time being such spontaneous forms of the Reformation propaganda stopped at the linguistic border. The Reformation first reached Polish intellectual and social elite. It began to penetrate broader masses with a delay (of 20 to 30 years, when it was already part of the nobility's political program) which was consequential, through clientele channels, in the widest sense of the word. With exceptions, of

4 B. Zientara, 'Cudzoziemcy w Polsce X-XV wieku. Ich rola w zwierciadle polskiej opinii średniowiecznej', in Swojskość i cudzoziemszczyzna w dziejach kultury polskiej, ed. by Z. Stefanowska, Warsaw, 1973, pp. 9-37; A. Wyczański, 'Uwagi o ksenofobii w Polsce XVI w.', ibid., pp. 68-79. 
course; no doubt small groups of dissenters spontaneously formed in some towns, for instance, Poznań. ${ }^{5}$

As the attempt to establish a state church in Poland failed, the task of organizing Evangelical rite was vested in nobility who initially offered refuge to dissenting preachers and, later on, especially in the fifties and sixties of the sixteenth century, took possession of Catholic churches. In private estates the decision to do that was made arbitrarily by the noble patron. But in the crown lands the starostas, even if vested with the power of patronage, were not completely independent. As I tried to prove elsewhere the campaign to appropriate churches in crown estates required a cooperation between the starosta and local residents, that is, mainly the groups ruling in towns. That is how the churches in Brojce, the Wschów, Międzyrzec and Drahim starostwo and nearly the entire Wałcz starostwo were taken over to accommodate the Protestant rite. The situation is not clear when it comes to the Ujsko-Piła starostwo which was located partly in the Wałcz powiat and partly in the Nakło powiat. In Kościan, where dissenters' position was strong for some time, the attitude of its starosta, Wojciech Czarnkowski, tipped the balance in favour of Catholicism ${ }^{6}$. In the crown lands situated far away from the border and inhabited solely by a Polish population even dissenting starostas either made no attempts at any modifications, or if they did, they were either short-lived or unsuccessful.

And although it would be an overstatement to claim that all Germans spontaneously espoused Reformation ideas, it seems that the difference in attitudes of the vast majority of Poles and Germans was clear-cut right from the beginning. ${ }^{7}$ However, involved in here is a risk of an ex silentio conclusion, as both in the crown lands and in the estates of dissenting nobility the subjects could have been under duress (enforced more or less effectively), and in some cases they were forced to do that due to a very long distance from Catholic churches that were still in operation. It does not always clearly follow from the available sources where burghers and peasants accepted the Reformation willingly and with conviction and where they tried to resist it.

5 J. Dworzaczkowa, 'Wprowadzenie reformacji do miast królewskich Wielkopolski', Odrodzenie i Reformacja w Polsce, 10, 1965, pp. 53-80.

6 Ibid., pp. 75-75.

7 Cf. Nowacki, op. cit., map IV, from 1602, which features characteristic concentrations of appropriated churches which overlap with areas of German settlement. 
Administrative duress, if applied consistently and for a sufficiently long time, turned out to be very effective, also in respect of the Polish population, as evidenced by the Duchy of Prussia or some Silesian duchies. But within the limits of Rzeczpospolita there was no say about it. In effect the town of Babimost ${ }^{8}$ remained Catholic, although Brojce located in the same starostwo espoused the Reformation. In the Wałcz starostwo, during the lifetime of Andrzej Górka (who died in 1583), there were Polish parishes in the villages of Skrzatusz and Witanków. In the Wieleń estate owned by the Górka family, in 1573 peasants built a Catholic church on their own initiative in the Polish village of Rosko, ${ }^{10}$ which was undoubtedly their response to the appropriation by dissenters of a parish church in Wieleń. It is evident that duress was either not exercised at all or quickly abandoned.

The influx of Evangelic settlers was a separate but a very important phenomenon - they migrated into Poland with established religious convictions. In the sixteenth century it was not as yet on a wide scale, as an intensive colonization campaign was carried out at the time mainly with the help of the local element. But dissenters found refuge in Leszno, established in 1547, and a buoyant Lutheran parish in Poznań mainly consisted of fresh newcomers. ${ }^{11}$ But that mainly applied to the areas situated along the Noteć River. In the Wałcz starostwo, in the part of Ujsko-Piła starostwo located on the west bank of the Gwda River, in the Wielen estates of the Gorka family and in the Człop estates of the Czarnkowski family villages were established where peasants would build on their own initiative a chapel, or at least a school, and would maintain Evangelic ministers and teachers. ${ }^{12}$ In later sources those villages were referred to as German, and in no village that was Polish beyond any doubt

8 Poznań, Archdiocesan Archive, Acta Vis. Posn. (hereafter, Acta Vis. Posn.), 3, 1. 122 , in 1603 there were only two haeretici germani in the town.

9 Nowacki, op. cit., p. 387.

10 Ibid., p. 578.

11 H. Kleinwachter, 'Das älteste protestantische Kirchenbuch der Stadt Posen', Zeitschrift der historischen Gesellschaft für die Provinz Posen (hereafter, ZHG), 9, 1894, pp. 108, 109.

12 The bibliography of the settlement in the Wałcz land is offered in Historia powiatu wateckiego, Poznań, 1964; F. Żmidziński, 'Osadnictwo w starostwie ujsko-pilskim do 1772 roku', Rocznik Nadnotecki, 1, 1966, pp. 49-69; O. Grossert, Evangelium und Deutschtum im Filehner Gebiet unter polnischer Grundherrschaft, Schönlanke, 1929, pp. 11-15, 24. 
one could come across an evangelical church. A similar phenomenon could be observed in the Nakło powiat; however, it is not possible to reproduce a network of Protestant churches in that area before the mid seventeenth century. The colonists could settle in the lands located along the Noteć River on relatively good terms. The so-called Schultheiss (village head) villages were established on similar terms as medieval towns and the very first Holländer settlements emerged.

The linguistic and religious polarity became fully conspicuous in the days of the former Catholic church repossession. In the crown lands of Great Poland the process continued over 1600-25. In those days Catholics recovered most churches in nobility estates owing to a high wave of conversions that occurred at the turn of the sixteenth century. Soon churches were also reclaimed by court orders from those members of nobility who continued to espouse the Reformation ideas, and a nobleman who nevertheless decided to build and maintain a Protestant church was not in a position to exercise coercion over his subjects. There is no doubt that Polish burghers and peasants usually willingly returned to Catholicism. And even if a peasant community managed to survive without the patronage of a nobleman, it would gradually become dwarfed and disappear. That process was most pronounced in the case of the churches of the Unity of the Brethren (Czech Brethren) at Szamotuły, Ostroróg, or Łobżenica. ${ }^{13}$ Even if it is revealed by future studies that such small groups of Polish dissenters were more numerous and that they lasted longer than it is usually thought, the crux of the matter will not change.

The residents who resisted compulsory reconversion to Catholicism and who organized their religious life anew and on their own terms were predominantly German. But Germans were presented with some options of voluntary conversion which were not fully taken advantage of. Representative is what a Lutheran woman of Pieski village (where the church continued to be closed although an evangelical minister had been ousted) said at the time of the Poznan diocese visitation in 1603: 'people are so thirsty for the word of God that they would listen to anyone'; the inspector took note that it was hard to find a German preacher in that area. ${ }^{14}$

13 I have discussed that problem in a monograph on the community of the Czech Brethren in Great Poland (in preparation).

14 Acta Vis. Posn., 3, 1. 26. 
The shortage of German speaking priests, which was so frequently experienced, was one of the factors making it difficult for the Catholic Church to take control over the situation. Another problem was a short-sighted rapacity of rectors in freshly recovered parishes who more often than not alienated the local population by excessively fastidious enforcement of their financial claims. On the other hand, the Jesuits in Poznań were very successful in their propaganda activities - their missionary excursions reached as far as the border with Silesia or Brandenburg. ${ }^{15}$ In 1618 Jesuits settled in Wałcz and were also successful there.

Some groups of German population converted to Catholicism when threatened with expulsion. In private estates such situations were rather rare (Tuczno, Sieraków); the nobility would rather leave their Evangelical subjects in peace. In the church estates more assiduous efforts were made to get rid of dissenters or to force them to convert. In the crown lands the resistance put up by Wałcz was broken down by force: its starosta, Jan Gostomski, acted with a passion of a neophyte. Whereas the residents of the Drahim starostwo, Międzyrzecz, Skwierzyny, Wschowy and Brójec managed to defend their freedom of religion and public worship. They were mostly Germans, but in Międzyrzecz there also lived Polish Evangelicals.

Most of the Germans living in Great Poland made a choice not only between the Reformation and Catholicism, but also between Lutheranism and the creed of the Czech Brethren. Rafał Leszczyński managed to impose the Czech denomination on his German subjects in Leszno and neighbouring villages. ${ }^{16}$ However, Germans tended to join the Czech Brethren only where they were dispersed, but where they lived in a bigger group they looked for their own Lutheran preacher.

The only exception in this regard was a small German parish of Czech Brethren that coexisted in Poznań with a much more numerous Lutheran one. ${ }^{17}$ The Germans also made another choice: they opted in favour of

15 Cracow, Jagiellonian Library, Ms. 5198, Annales Collegii Posn. SJ, vol. 1: the missions which operated also among Germans in 1583-1600, in Gostyń 1. 21, in Grodzisk 1. 30v, along the Silesia borderline 1l. 39v, 40, 64, in Krotoszyn 1. 42v.

16 Apart from Leszno there were churches of the Czech Brethren in Lasocice, Niechłód and Gołanice. In the seventeenth century the owners of Jędrychowice and Kowalew maintained the ministers of the Czech Brethren (and then Calvin ministers), but the local peasants were Lutherans.

17 According to S. Waszak, 'Dzietność rodziny mieszczańskiej i ruch naturalny ludności miasta Poznania', Roczniki Dziejów Spotecznych i Gospodarczych, 16, 1954, p. 
'unmodified Augsburg confession' (Augustana invariata) among orientations that existed in Lutheranism, and were very reluctant and even hostile towards the so-called Sandomierz Consensus. The position taken by the Poznań parish on that subject is sufficiently clear. Not all German parishes joined the Great Poland organization of the Lutheran Church where in those days a leading role was played by the nobility who were Polish and recognized the 'consensus'. Which means that to the Germans the maintenance of unity with co-believers across the border was more important than common interests of dissenters in the Rzeczpospolita. Moreover, they approved of those features of Lutheranism which made it distinct from other Evangelical denominations. What the Germans found in Lutheranism was undoubtedly a confirmation of their ethnic distinctness, ${ }^{18}$ and they adopted as their own also other features of that religion which, however, is too vast a subject matter to be discussed in respect of a small territory, enclosed inside political and administrative borders. It should only be said that in Rzeczpospolita Lutheranism played a very important role as a factor integrating individual self-governed municipal and rural parishes.

That the Germans were more susceptible to Reformation than Poles was evident already to their contemporaries, although it is hard to identify the moment when the stereotype discussed in here came into use. One may assume that a German was identified as a Protestant earlier than a Pole as a Catholic, and the latter initially applied only to the plebeian population. Although most of the Polish nobility also remained Catholic, the dissenting minority played too important a role in the life of the country to claim that Catholicism was an inseparable feature of a Polish nobleman. However, a German nobleman was considered a dissenter a priori. ${ }^{19}$

That was the situation when the Thirty Years' War broke out and soon spread over Poland's neighbours. In those days Great Poland experienced

332 , at the end of the sixteenth century a German Lutheran community could comprise 2400 people, a Polish one - ca. 200 people, and a parish of Czech Brethren - 200-500 people. There are no data on the ratio between the number of Poles and Germans in the parishes of Czech Brethrens.

18 J. Tazbir, Rzeczpospolita $i$ swiat, Warsaw, 1971, p. 32.

19 For example, at the beginning of the seventeenth century bishop Jan Tarnowski, when he tried to prevent Unrug, the owner of Międzychód, from another appropriation of the church, threatened him that he would cause the adoption of a law by parliament prohibiting German nobility from buying estates in Poland. Nowacki, op. cit., p. 468. 
acute symptoms of the economic stalemate: falling population and declining towns. Publicists suggested that it was necessary to rehabilitate towns and to revive the internal market. In that situation the crowds of refugees fleeing across the border were welcomed by magnates and nobility. In the area along the Noteć River there were many Evangelical immigrants from Neumark and West Pomerania. They were moving into the existing towns and villages or established new settlements, in some cases they were also granted permission to build a church. Of incomparably greater significance was the influx of refugees from Silesia who were fleeing not only from the consequences of wartime activities but also from religious persecution. As we know, many new towns were established owing to that Silesian migration, especially in south western Great Poland. ${ }^{20}$ The dimension of rural colonization from that direction is harder to capture; anyway, it was not on such a scale that could stop the agrarian crisis. But as a result of the influx of Silesians seventeen new Lutheran parishes emerged in towns and an indefinable, though rather small number in rural areas, and the existing churches gained a significant number of new worshippers.

The Silesians frequently migrated in large groups and tried to settle together. At least three thousand residents of Góra Śląska moved to Leszno, and many immigrants settling in Wschów came from Głogów, in Babimost - from Świebodzin, in Zduny - from Dzierżoniów. They were mostly craftsmen, of whom weavers and clothiers constituted the most numerous professional group. But they also had their own elite: former municipal officers, lawyers, pastors and teachers, occasionally there would also be a teacher, doctor, pharmacist or printer. Some of them would write, creating their own, rather lowbrow but highly individualistic literature. ${ }^{21}$ Their journey eastwards was in an atmosphere of religious exaltation; they considered themselves as religious martyrs regardless of their individual motives of emigration.

The situation they encountered in Great Poland was as follows. The local Evangelical Church of Augsburg Confession was completely disorganized, German communities lived their own lives, and a small group of the rest of the Polish nobility seriously negotiated their alliance with

20 Z. Kulejewska-Topolska, Nowe lokacje miejskie w Wielkopolsce od XVI do końca XVIII w., Poznań, 1964.

21 A lot of material regarding that problem is offered by P. Voigt, Aus Lissas erster Blütezeit, Lissa, 1906. 
the Community of Czech Brethren which was at the time on the eve of its unification with the Calvinists. Owing to Silesian refugees the church organization experienced a revival in 1634. Although its first superintendent, Kasper Diering, came from Poznań, and the representatives of Polish nobility were nominated as patrons, that is, senior laymen, the influence of Lutheran ministers from Silesia was enormous. That is why the opponents of any accords with Calvinism got the upper hand, coming out as winners from the test of strength in the form of Colloqium Charitativum in Toruń in 1645.

With as significant an influx of Germans and their dominant position in the Lutheranism of Great Poland, no wonder that the stereotype became so pronounced in those days. When reference is made to the 'German church' or 'German religion'22 in everyday Polish, it is not necessary to explain what religion is meant. And vice versa. In 1640 a Catholic visitator, father Lutolu, said about the Międzyrzec starostwo: 'all residents of this village used to be Polish and Catholic and now they are all German and Lutheran, so it is likely that the so-called Polish confession, as the Germans call it, used to flourish here'. ${ }^{23}$ And that in spite of the fact that among the newcomers one could sometimes come across Poles who were of Evangelical denomination and Germans who were Catholic, for whom special preaching offices were established. It should be noted that so strong an association between language and nationality stopped on Poland's western border. Silesia was a very complex linguistic and religious mosaic, but it was especially in the lands bordering on Great Poland, such as the duchies of Syców, Głogów, Wołów, Krosno and Świebodzin, that there lived many Poles who were Evangelicals.

How did the local people react to that significant influx of foreigners? Immigration was in the interest of feudal landlords whom no one was able to oppose successfully. King Sigismund III Vasa issued a mandate prohibiting accepting a-Catholics in royal towns, but it was not observed by all starostas. Among the Polish populace there must have been reactions

22 For example, in 1621, a janitor paid a visit to a 'German church' at Śmigl at the request of a 'common man of German confession', Poznań, Archiwum Wojskowe [Military Archive], Gr. Kość., 115, 1. 1000v.

23 'Notandum est, olim in hac villa omnes fuisse Polonos (iam vero omnes Germani et lutherani), atque ideo probabile est fidem etiam olim Polonam, quoc a Germanis vocatur catholicam, hic viguisse'. Acta Vis. Posn., 10, 1. 74v. 
of spontaneous dislike of foreigners, ${ }^{24}$ but it is hard to establish if they were the outcome of a significant sense of threat. For example, a 'new town' could have been viewed by well established burghers as an unwelcome competition. Most opposed of all were the residents of Wschów, ${ }^{25}$ that is, people speaking the same language and of the same religion as the immigrants. Whereas the city council of Kościan stood in defence of the newcomers, who had been harassed by the rector, arguing that without their assistance the town could not bear the burden of public taxes. ${ }^{26}$ When Silesian Evangelicals were building Zduny, the residents of a small rural town of Stare Zduny, Poles and Catholics, helped them carry timber for their church. 'Welches ein Wunder ist fur unseren Augen', ${ }^{27}$ it was recorded in the church chronicle. Did they perceive the establishment of a new town as a window of opportunity for themselves? It happened in some villages that landlords ousted Polish peasants from their dilapidated homesteads to make room for new colonists, but one can hardly speak of expulsions in the proper sense of the word. The newcomers mainly filled the gaps that existed after runaway peasants or epidemics, and sometimes they built villages from scratch. And although the rise of xenophobic sentiments in Great Poland in the 1730s seems to have been an obvious phenomenon, it mainly manifested itself by a spymania, ${ }^{28}$ which may be convincingly explained by the recent war with Sweden and various armies fighting in Germany that crossed the border. In those years of overall anarchy and lack of safety, even a few murders of Evangelical ministers cannot be interpreted unequivocally.

24 In a privilege vested in Bnin (which was not exercised) in 1636 Zygmunt Grudziński assured prospective settlers, 'weil auch zu Pestzeiten die teutschen von den Polen oftmals verjagt werden', that they would be able to organize their own care of the sick, W. Bickerich, 'Sigismund Grudziński der Kolonisator und seine religiöse Stellung', Aus Posens kirchlicher Vergangenheit (hereafter, APKV), 2, 1912, p. 105. The Czechs who came to Leszno criticized their German co-worshippers of nonhumanitarian treatment of the sick, cf. idem, 'Ein Kampf um christliche Liebestätigkeit in der Pestzeit', Innere Mission, 2, 1907.

25 H. Wuttke, Städtebuch von Posen, Leipzig, 1877, p. 304.

26 Lustracja województw wielkopolskich i kujawskich 1628-1632, ed. by Z. Guldon, Wrocław, 1967, p. 67.

27 A. Henschel, 'Geschichte der evang. Gemeinde in Zduny', ZHG, 4, 1889, p. 5.

28 Relacja posta księcia Bogustawa XIV z podróży do Wielkopolski w 1633 r., ed. by H. Lesiński, Szczecin, 1959. The cases of distrust of travelers wearing strange clothes may be found in county records. 
Religious privileges vested in newly established parishes usually included a permission to build a church and a school, to pay a minister and to administer religious ceremonies in public. The local Catholic rector was paid a 'pro administratione sacramentorum' (usually in lump-sum). In the case of a trial the privileges could serve as evidence before the court, as in principle a landlord had the right to grant religious freedom to its subjects. The scope of such freedom was usually tolerated by burghers with limited aspirations so long as promises they had been given were observed, and payments to Catholic clergy did not exceed a tolerable level. The Catholic landlords not only did not oppose subjects of another denomination, but it may be imagined that they found them convenient. A landlord who became a guarantor of his subjects' religious freedom made them even more dependent on him and also could gain a good pretext to force additional allegiances from them. Moreover, among the Catholic clergy there were priests who had nothing against the presence in their parish of people who would pay dues only to be left alone. It was an opportunistic attitude which was condemned by more zealous clergy, but it was nonetheless there. That is how attempts were made to reconcile highly divergent interests for the benefit of the region's economic interests. It is, however, easy to understand that the situation was not propitious to assimilation tendencies, be they active or not.

In that context the Polish Swedish War of 1655-60 brought about less significant changes than one could expect. Growing animosity towards dissenters in the Polish society as a result of the 'deluge' and its long-term consequences are well known. But that animosity was not so profound to make the Great Poland nobility agree to the loss of their dissenting subjects who were seeking refuge on a mass scale in Silesia and Brandenburg in 1656. Attempts were made to bring them back by, for instance, the approval of religious privileges. In few cases the clergy managed to talk landowners into ousting protestant ministers and teachers from their lands and ordering their subjects to baptize their children in Catholic parish churches. ${ }^{29}$ King John II Casimir Vasa renewed the ban on granting municipal rights to a-Catholics in some royal towns.

29 The mandates issued by 'some magnates' which ordered to baptize heretics in the Catholic Church, to go to Catholic confession and first communion are mentioned in Historia residentiae Valcensis SJ, ed. by M. Rohwerder, Cologne, 1967, p. 111, where it is dated to 1674 . 
However, the ban was not strictly observed and, for example, in Poznań did not prevent the emergence of a group of rich dissenter merchants.

The situation between the two Northern Wars was as follows. Though less numerous than before, there was an influx of Protestant settlers; in consequence a few small towns and a lot of villages were established, the Holländer settlement was growing. But it was rare for dissenters to be granted privileges allowing them to build new churches. And that is why the role of a school and a teacher, cantor and Vorleser, began to rise, as he not only taught children Catechism and reading, but also headed Sunday services and read sermons from a printed postil. In some parishes he would also baptize children and administer funerals or even marry people. ${ }^{30}$ Owing to schools the Evangelical worship could persist over generations, even in locations distant from any church. There were also cases of Germans converting to Catholicism, ${ }^{31}$ and the small group of Polish Evangelicals was on the decrease. The Catholic church authorities, which had to come to terms with German protestants, tried to prevent any influence they could have on the Polish population and ardently fought against services in the Polish language.

The Northern War was another turning point as it made religious antagonisms more pronounced. The Constitution of 1717 not only prohibited building of any new Protestant churches, but also made it possible in practice to close down every existing one. Soon afterwards the dissenting noblemen were deprived of their political rights which was tantamount to their exclusion from the nobility estate. It was a widespread feeling that dissenters were an alien element in the organism of the Rzeczpospolita. On the other hand, however, after the ravages of the war and the plague that had to be repaired, and later on due to an increasingly faster growth of the region, it was necessary to bring settlers from abroad, which problem continued to be highly topical. The immigration of Germans contributed to the economic growth that occurred in Great Poland in the eighteenth century and German scholars tend to label it as the 'third colonization' which Polish historians estimate at 25-30 thousand

30 W. Rusiński, Osady tzw. 'Olędrów' w dawnym województwie poznańskim, Poznań and Cracow, 1939-47, pp. 117-20.

31 In 1677 the Jesuits in Wałcz managed to convert only six people as apart from one preacher no other monk speaking German lived there. Historia residentiae..., op. cit., p. 113. In earlier years several dozen conversions used to be recorded, and in 1670 as many as 127 , ibid., p. 104. 
people. ${ }^{32}$ There is no doubt that settlers were harder to be found than in the days of the Thirty Years' War. As the Prussian monarchy was gaining power, it tried to prevent the outflow of population from its territory, and in the days of the colonization of the estuary of the Noteć River by Frederick II many peasants migrated there from Great Poland. However, some regions which had been Polish until then became strongly saturated with the German element. That particularly applied to the area around Nowy Tomyśl, Zbąszyń and Wolsztyn, the lands along the Warta River from Skwierzyna through Oborniki and a strip east of Czarnków as far as Bydgoszcz. Which resulted in a much more energetic counteraction on the part of the Catholic clergy than before. Soon after the war was over the alarm bell was clanged by the Poznan bishop, Krzysztof Antoni Szembek, who was later nominated archbishop of Gniezno. In his letter written in 1718 against the gravamina of dissenting noblemen, he emphasized the danger of heretics flooding the country and argued that the invitation of Protestant settlers posed a threat not only to the Church but also to the state: 'it is etiam contra statum as we would have been slowly bought out by vicini, and haeretici would have extirpated the Catholics'. ${ }^{33}$ And although Szembek was against the immigrants of 'alienae fidei et linguae', ${ }^{34}$ it was not the language that he had in mind. He is attributed the idea of bringing Catholics from southern Germany. ${ }^{35}$ However, the immigration from those distant lands did not reach a major scale before the Partitions.

In the community of Catholic clergy there were plans of not only stopping the influx of Protestant settlers but also of forcing those who had already settled in the country to convert to Catholicism and to expel the stubborn ones. They sparked some reaction of the Polish nobility which was undoubtedly caused by a sense of threat to the existence of the state. But the idea of expelling dissenters was doomed to fail as it was acutely aimed against the economic interests of landlords. The discussion whether to bring the dissenters or not continued as long as the Polish state existed. A variety of opinions were voiced: from zealots claiming that it was a disgrace to 'the growth of crafts and commerce' to act against the religion, to 'Kameralisten' who argued that every activity to promote

32 Dzieje Wielkopolski, op. cit., pp. 813, 814.

33 Listy Jana Sobieskiego, ed. by A. Helcel, Cracow, 1860, p. 575.

34 Ibid.

35 M. Bar, Die 'Bamberger' bei Posen, Poznań, 1882, p. 8. 
the growth of the country's population and wealth was fair. ${ }^{36}$ In between those extreme attitudes there was space for more moderate discussion on the required scope of religious freedom and also if it was at all required in order to keep the dissenters within the borders of the Rzeczpospolita. ${ }^{37}$

The issue of religious tolerance for their subjects was in practice approached by the Catholic landlords in various ways. Some of them tried to provide them with the broadest possible scope of freedom, others succumbed to the pressure of the clergy and permitted repressions, still others lent their hand to those repressions. The initiative usually came from the clergy, but it is hard to determine when the real aim of various harassments was to make dissenters change their faith, when they were merely a manifestation of the Catholic Church's power, and when they simply served as a pretext to gain additional material benefits. It was also hard to ensure a full coordination between actions taken by patrimonial authority and clergy, and the latter were not always in haste to kill a hen laying golden eggs. In effect at least forty Lutheran churches were closed down, dissenters had to pay numerous charges in favour of the Catholic clergy and sometimes they were even forced to take part in Catholic services. On the other hand, rare were direct orders to convert or to raise children as Catholics; landlords feared that as the last resort people would decide to flee. In fact the stronger parishes were in no danger as they could always redeem themselves. Some weaker ones, when under strong pressure, would begin to crumble, although persecution frequently resulted in even stronger opposition. It will have to be examined closely to what extent repressions multiplied the number of German Catholics. ${ }^{38}$ Their results were not, however, impressive. Over 1775-93 in Great Poland (excluding the lands over the Noteć River lost during the First Partition) 32 new Evangelical churches were opened. Which only shows a great disparity between the number of dissenters and the number of churches

36 K. Zimmermann, Fryderyk Wielki i jego kolonizacja na ziemiach polskich, vol. 2, Poznań, 1915, p. 160.

37 J. Michalski, 'Sprawa dysydencka a zagadnienia gospodarcze w opinii publicznej w pierwszych latach panowania Stanisława Augusta', Przegląd Historyczny, 40, 1949 (1950), pp. 156-163.

38 The Jesuits of Wałcz converted 80 people in 1719 and 37 over 1720-21; most probably it was due to the closing down of several Protestant churches in the area of their activity, Historia residentiae..., op. cit., p. 175. In the following years, until the First Partition, the number of conversions was very low. 
they used to have. It is also noteworthy that in at least 17 cases Catholic landlords assisted them by providing building materials and money; ${ }^{39}$ most probably they seriously reckoned with their Evangelical subjects.

After the First Partition the number of German Catholics in Great Poland was estimated at about 10 thousand, and of Lutherans at more than 200 thousand; ${ }^{40}$ these are, however, quite arbitrary estimates as the Prussian statistics frequently offered only religion and not the nationality of the residents of annexed lands. There was a bigger community of Catholics in the Wałcz land which was annexed in 1772. It is possible to carry on further studies on that subject as in Catholic parishes of western Great Poland one may still find numerous birth certificates and their records abound in German names. ${ }^{41}$ The largest community of German Catholics lived in church estates. But even such towns as Wschowa or Międzyrzecz lost their exclusively Evangelical character in the eighteenth century partly in the aftermath of the influx of the Polish population and partly owing to the conversions of Germans. Quite different, of course, was the origin of settlements established by Catholics from Bamberg and Swabia.

On the other hand, in the eighteenth century there was a significantly higher influx of Poles-Evangelicals from Silesia who mainly settled in the Ostrzeszów powiat (outside the borders of Great Poland proper), but also in the Odolany starostwo which was part of the Kalisz province. ${ }^{42}$ They felt to be clearly distinct from the local residents and it is easy to understand that neither the existence of that regional peasant group nor the presence of individual Poles-Evangelicals dispersed in Holländer villages ${ }^{43}$ could prevent the synonymous use of the notions of 'Pole' and 'Catholic'. The status of German Catholics was higher and it seems that

39 On individual Evangelical churches, A. Werner, J. Steffani, Geschichte der evang. Parochien in der Provinz Posen, Poznań, 1898.

40 A. Rhode, Geschichte der evang. Kirche im Posener Lande, Würzburg, 1956, p. 129.

41 Collected in the Archdiocese Archive in Poznań.

42 K. Kotula, Polski lud ewangelicki w potudniowo-wschodniej części województwa poznańskiego, Warsaw, 1929. Cf. R. Rhode, 'Die polnischsprechenden Evangelischen in Südposen', Posener Evangelisches Kirchenblatt, 6, 1927-28, 6. At the end of the eighteenth century Polish Lutheran services were offered in Great Poland proper only in Odolanów and Kargowa, and in the Ostrzeszów powiat - in Kępno and Ostrzeszów. About Polish Evangelicals in the area around Kargowa, see M. Sczaniecki, $Z$ dziejów polskości na ziemi lubuskiej, Poznań, 1948, pp. 11-12.

43 Rusiński, op. cit., pp. 32-33. 
it was hard not to notice their presence. In spite of the foregoing the notions of 'German' and 'Lutheran' were also synonymous and more often than not reflected the reality. For example, in the 1700 inventory of a little town of Mrocz its residents were divided into 'Germans' and 'Catholics'. ${ }^{44}$ When establishing an Evangelical parish at Wieleń in 1745 Piotr Sapieha defined the pastor's authority over the Germans living in the Wielen estate. ${ }^{45}$

However, the above facts do not exhaust the topic. Because it is not indifferent to our discussion that the word 'German' was a synonym not only of a Protestant but also of a free man enjoying better rights than indigenous residents. That notion does not directly come from the days of the first medieval colonization because in time the 'German law' ceased to be associated with nationality. Nonetheless, as the corvée was spreading since the sixteenth century and personal serfdom was becoming more acute, and new colonists, who were predominantly German, were granted better rights, then the notion of the 'German freedom was revived'. Silesian burghers who were looking for new domiciles during the Thirty Years' War feared that in the Rzeczpospolita they might fall 'in polnische Leibeigenschaft', ${ }^{46}$ and they were assured by their prospective landlords that their 'deutsche Freiheit' would be ensured. ${ }^{47}$ It was tantamount to personal freedom and freedom from labours frequently imposed on the residents of small towns. The freedom of the Augsburg confession, though it is not covered implicite by that notion, was undoubtedly associated with it.

The differences in the legal standing of a German burgher in Silesia and of a Polish one in Great Poland could be noticed in fact only in small towns. In major royal towns their residents enjoyed a full range of municipal rights, even if they fell victim of various abuses by nobility officials. In the countryside, on the other hand, the situation of Germans was highly diversified. In the eighteenth century there were also villages

44 Materiaty do dziejów chtopa wielkopolskiego, ed. by J. Deresiewicz, vol. 2, Wrocław, 1956, pp. 398-401.

45 Grossert, op. cit., p. 40.

46 Henschel, op. cit., p. 2.

47 A. Warschauer, 'Reklamblätter zur Heranziehung deutscher Kolonisten', ZHG, 1898, p. 58 - an appeal for Kobylin, p. 208 - for Babimost; Privilege for Babimost, J. Kohte, 'Urkundliches zur Geschichte der evang. Pfarrkirche im Bomst', ZHG, 10, 1895, p. 147; privilege for Bnin, W. Bickerich, 'Sigismund Grudziński', APKV, 2, pp. 101-06. 
of old, medieval origin, where peasants had to work the highest possible corvée $^{48}$ and as subditi nativi were the object of various transactions. ${ }^{49}$ There were villages with hereditary village head positions where corvée was moderate, usually of three days, there were also Holländers and other peasants exempted from corvée for an annual rent. Not infrequent were also settlements where Poles and Germans lived side by side and were encumbered by the same burdens. ${ }^{50}$ As the end of the century approached, the Holländer villages settled by Poles could be encountered more and more frequently, the number of Polish independent homesteads of another type was rising so as the number of free, contracted peasants. Nonetheless there were few German serfs compared to the Polish ones, the Holländer settlement was initially predominantly non-Polish and sharp contrasts were frequent: German villages paying rent existed side by side with Polish corvée villages, or in the same area the corvée imposed on Poles was much higher than that imposed on Germans. ${ }^{51}$

However, not the statistical mean but the foregoing contrasts shaped the social awareness. When describing the Noteć River area during the Second Partition, a Prussian statistician, August Karl Holsche, referred to 'Untertanen, Scharwerks oder polnische Bauern' ${ }^{52}$ while treating free villages' heads, tenants (emfiteut) and Holländers as Germans, without specifying the nationality of contractual settlers. ${ }^{53}$ If nationality had not been so strongly connected with legal standing, it would most probably

48 For example, in Świdnica (today Siedlnica), each day two, Materiaty do dziejów chtopa..., op. cit., vol. 1, p. 466; in Łysin every day in summer, 9 days in winter, ibid., pp. 46 ff. Cf. Historia powiatu wateckiego, op. cit., pp. 137-38.

49 Meaningful examples from the Golec family estate in Wałcz powiat, see Transakcje chtopami w Rzeczypospolitej szlacheckiej, ed. by J. Deresiewicz, Warsaw, 1959, pp. 176-79, 185, 186.

50 For example, Grabionna in the Nakło powiat, Materiaty do dziejów chtopa..., op. cit., vol. 2, pp. 358, 359; Dziewierzewo - ibid., pp. 209-10.

51 For example, in 1771 in the Mrocz estate settlers with German names living in the villages of Gliszcz, Ostrowo, Tomino, Kosowo paid a rent, Polish peasants in Drążnia and Małocin worked corvée, ibid., vol. 2, pp. 365 f. On different burdens that were imposed on Polish and German villages, F. Żmidziński, Zmiany w obciązeniach ludności wiejskiej w staroststwie ujsko-pilskim od XV do XVIII w., Poznań, 1971 (Prace Komisji Historycznej PTPN, 26, 1), pp. 213-15; the author also points out that the 'encumbrance by corvée decreased during the eighteenth century and it was replaced by other performances'.

52 A. C. Holsche, Netzedistrikt, Königsberg, 1793, p. 214.

53 Ibid., pp. 216-23. 
have not been identified in the landowner sources, because the language spoken by their subjects was unimportant to estate administrators. Whereas it is not uncommon in registers, etc.; even though Polish second or even first names may be encountered now and then among the 'Germans'. ${ }^{54}$ The notion of a German, and therefore a dissenter, was, however, commonly associated with a free settler, vested with rights to his movable property, and of a Polish peasant - with a Catholic enslaved by corvée.

Excellent examples in that regard are provided by Stefan Garczyński’s Anatomia Rzeczypospolitej:

Niech ciekawość czyja zlustruje wsie dysydenckie [...], a i w przywilejach ich zobaczy, że w każdej ich wsi więcej kmieć od jednego śladu swojemu dziedzicowi nie płaci czynszu tylko talerów dziesięć albo dwanaście a e converso, gdy kmieć polski, chłop katolik, na równym śledzie zasiądzie, musi co dzień panu trojgiem zaciąg robić [...]. Niech tedy każdy roztropnie zważy, jeżeli to nie jest w samem rzeczy eluzja z Pana Boga, prosić go po kościołach, przed świętemi ołtarzami, o egzaltacją kościoła św. katolickiego, o poniżenie herezji; a jakżesz to być może, gdy herezji w swych dobrach przy wolności żyć pozwalamy, a swoich katolików w opresji nieporównanej zachowujemy, sposób życia im odbieramy. Często ichmość dziedzicy taki dyskurs prowadzą ze sobą, inculpando poddanych swoich, że są gnuśni, ręce opuszczają i nic sobie nie tylko nie budują, ale nawet zbudowanej nie poprawią chałupy. A tego nie uważają, jak onemu gospodarzowi ma być miłe życie, gdy go włodarz z batogiem na zaciąg bez najmniejszego wypoczynku wypędza. ${ }^{55}$

Which observation is the more so noteworthy that it juxtaposes an indolent Catholic and a more enterprising Protestant. Garczyński returned to that subject on several occasions comparing Catholic cities and towns with those that were also inhabited by dissenters (particularly interesting is an observation he made elsewhere that: ' $\mathrm{i} u$ nas, gdzie krypel luterski znajduje się, to i katolicy przy nich per imitationem czysto, porządnie chodzą,56). Anatomia also offers a reflection on the reasons behind a lower level of economy and civilization in Catholic countries, that is,

54 For example, Kazimierz Wąsoski at Fałkowo, Materiaty do dziejów chtopa..., op. cit., p. 3, or Andrzej Nowak at Sokołów near Kcynia, ibid., p. 127.

55 S. Garczyński, Anatomia Rzeczypospolitej, [Wrocław], 1753, p. 128.

56 E. Rostworowski, 'Spór S. Garczyńskiego z braćmi Załuskimi o rolę duchowieństwa w “Anatomii Rzeczypospolitej”, in O naprawe Rzeczypospolitej, Warsaw, 1965, p. 219. 
on the phenomenon that was evident to contemporaries at least from the mid-seventeenth century and which continues to intrigue scholars to date. Garczyński thought that it was necessary to seriously argue with opinions which, as he claimed, he had heard on many occasions, that 'mizeria obywatelów jest to, quid connexum do naszej wiary' (the misery of citizens is quid connexum to our faith), because God allows heretics, who are far away from the divine kingdom, to enjoy the wealth on this earth, while Catholics are to be rewarded for their present destitution in the other world. ${ }^{57}$ That fatalism was unacceptable to the Poznan province voievode as well as to later Enlightenment publicists. He believed that servitude and ignorance rather than supernatural factors were the causes of that evil, and a minimum of freedoms and education granted to subjects had to produce positive results, also in the economic sphere. It was in the next century that it became fully evident what achievements the Great Poland peasant was capable of. For the time being even the Catholics associated their confession with poverty and neglect; it is beyond doubt that Protestants shared that conviction, so flattering to them.

Involved in his observations was a mystification of sorts which is much harder to verify than the legal status of Polish and German residents. For didactic purposes Garczyński resorted to simplifications, for example, by comparing towns of completely different sizes, ${ }^{58}$ which were in fact incomparable. However, the juxtaposition between wealth, industriousness and order, on the one hand, and poverty, passivity and destitution, on the other, added a final shape to the discussed stereotype. It was as early as in the days of the Partitions that it was taken up and turned into a caricature by Prussian publicists who thus tried to justify the annexation and to convince the population of the occupied lands of the benevolence of the new authorities, thus encouraging voluntary Germanization which was to be tantamount to the raising of their wealth and civilization status. In the discussions between Polish and German historiographers conducted later on in the nineteenth and twentieth centuries the German nationalists viewed that stereotype, which had been formulated in an extreme way, as an accurate reflection of reality. Polish scholars spared no effort to prove that the reality was different and to reduce the economic and civilization role played by the German

57 Garczyński, op. cit., pp. 212-15.

58 For example, Kościan with Leszno which was at least six times bigger, ibid., p. 131. 
population to proper dimensions. Nevertheless, that stereotype is by no means a subsequent scientific or pseudoscientific construct, it existed in the days preceding the Partitions and was then present both in the awareness of Poles and Germans, affecting the reality in some way.

Here again we tread a territory which is very hard to verify. To what extent the foregoing affected the economic decisions of nobility and preferences shown to Germans, and to what extent it was dictated by objective necessity - they would take colonists wherever they could find them and on the terms they could get. But it may be presumed that the nobility also recognized the merits of Germans. Which was not in contradiction to the Sarmatian xenophobia. German plebeians had traits welcome in a subject; but on the other hand, the culture of the German nobility was not appreciated by Poles.

It does not need any proof, however, how important that stereotype was to the Germans living in Poland, how it strengthened the sense of their worthiness and distinctness. In the pre-Partitions Great Poland the social structure of the German population was incomplete because the Evangelical nobility of German descent was not numerous and lived on a linguistic border. German burghers, not only merchants, but also more ambitious craftsmen, viewed fluency in the Polish language as very important. It was a widespread custom that their sons, and sometimes even daughters, spent a few years with Polish families to learn Polish ${ }^{59}$. Polish was needed for professional reasons, the fluency in that language was probably an evidence of social urbanity, but it was not an introduction to Polonization. Barriers between estates were particularly high in the seventeenth and eighteenth centuries. We know that they were never broken through, and social advancement, which is a very important stimulus of assimilation, was very slow. The German language and Protestant faith would rather facilitate than hamper the advancement of a plebeian who had neither prospects nor ambitions to become a member of the nobility estate. No matter if it was payment to be admitted to a tenement village or a guild, or an attempt to become a journeyman, or professional

59 Cf. T. Wotschke, 'Geschichte der Kirchengemeinde Rawitsch', APKV, 2, pp. 43-44; idem, 'Das evangelische Provinzialgymnasium in Bojanowo', ZHG, 24, 1909, pp. 186-90. A poor school in Rawicz (the second largest town of Great Poland in terms of population) was explained by the fact that parents sent their children to those schools where they were able to learn Polish. Information that children were sent to learn Polish may be found in various sources. 
contacts with nearby towns beyond the western and northern borders, or moving from a small town to one of the major cities in Great Poland, an Evangelical denomination and a certificate that one was of a decent German descent (which was frequently formulated as: 'non Venedic or any other despicable one') was viewed as a tangible and practical asset. ${ }^{60}$ It does not matter that there were Catholic guilds that did not accept dissenters and in some smaller towns a-Catholics were refused municipal rights. In the eighteenth century there were 15 towns with more than 2 thousand residents in Great Poland; in 10 of them dissenters accounted for more than 50 per cent of the Christian population, and in seven of them - for more than 75 per cent. ${ }^{61}$ The prospect of becoming a member of the Polish burgher estate was not particularly tempting. Therefore, more susceptible to assimilation were manor servants, clerks, and tenants. Quite different mechanisms underlay the Polonization of German Catholics. Which is an important but insufficiently known process, topical in the times preceding and following the Partitions. ${ }^{62}$

Thus religion was a very important, though not the only factor which prevented the Polonization of Germans. Although religious differences did not make marriages impossible, they made them more difficult. Religion determined the relations between an individual and one of the distinct, though overlapping, cultural circles. But first and foremost, it drew a sharp borderline between the two communities. One could be bilingual and feel no need to identify one's national allegiance, but one was either a Catholic or an Evangelical.

Everything seems to indicate that in Great Poland before the Partitions the Catholicism's Polonizing role was not significant, and the Germanizing role of the Reformation was almost null. Faith merely consolidated a division which was due to completely different reasons. A decisive role

60 Grossert, op. cit., quotes a certificate issued in Nowe Kwiejce in 1706: 'alten, deutschen, redlichen Geschlechts und Geblüts, auch nicht wendischen noch anderen verachtlichen Herkommens'. About the 'Venedic paragraph' in the towns of Brandenburg, for instance, W. Vogel, Der Verbleib der wendischen Bevölkerung in der Mark Brandenburg, Berlin, 1960.

61 Those calculations are based on the so-called Prussian indaganda; see Opisy miast polskich z lat 1793-1794, ed. by J. Wąsicki, Poznań, 1962.

62 Cf. S. Kieniewicz, Spoteczeństwo polskie w powstaniu poznańskim 1848 r., Poznań, 1935, p. 35. On Polonization of the residents of villages near Poznań, Bar, op. cit., pp. $35-50$. 
was played by migration processes. That is why the Great Poland sources do not contribute much to the explanation of a fundamental problem, that is, the reasons why the Polish population was less susceptible to the Reformation than the German one. The origins of that phenomenon that dates back to the first stage of the Reformation are hard to retrieve from the sources, and the subsequent waves of Evangelical immigrants obliterate what may be viewed as internal and long-term processes. In effect the linguistic and religious divisions overlapped to such a high extent that both Poles-Evangelicals and Germans-Catholics became small minorities among their countrymen. Discernible in both groups are tendencies to overcome that inconvenient situation. Poles tended most frequently to return to Catholicism, Germanization applied only to individuals. The Polonization of German Catholics was most probably of a much wider scale. Theirs was a limited choice as they were not able to convert freely to Lutheranism; since 1668 there was a law prohibiting apostasy, but even prior to its adoption the tolerance of a dissenter from Catholicism was lower than in the case of an Evangelical by birth. On the other hand, German Evangelicals showed considerable resistance to re-Catholization attempts because, for instance, the Lutheran denomination epitomized not only an ethnic distinctness but also a long list of positive values which were especially valuable to those who were not members of the nobility estate. The repressions of Evangelicals, especially those in the eighteenth century which were to force them to convert, must have been insufficiently consistent or severe as they were not in the interest of the nobility. And in effect their outcome was insignificant.

In spite of the foregoing a study focusing only on one province cannot properly assess all factors involved and to determine the cause-effect relationship between them as it calls for a wider comparative approach.

\section{Translated by Alicja Adamowicz}

First published as: 'Reformacja a problemy narodowościowe w przedrozbiorowej Wielkopolsce', Odrodzenie i Reformacja w Polsce, 23, 1978, s. 79-101. 